\title{
PERBEDAAN EFEK PIJAT OKSITOSIN DAN PERAWATAN PAYUDARA TERHADAP PRODUKSI ASI PADA IBU NIFAS DI KOTA PEKALONGAN
}

\author{
Miftachul Jannah $^{1}$, Dian Kusumawardani ${ }^{2}$, Ana Setyowati ${ }^{3}$ \\ Email: itajannah88@yahoo.co.id \\ DIII Kebidanan AKBID Harapan Ibu Pekalongan \\ Jl. Sriwijaya No. 7 Pekalongan \\ Telp/Fax (0285)4416108
}

\begin{abstract}
Abstrak
Masa nifas adalah periode penting seorang ibu yang disertai dengan penambahan tanggung jawab baru, yaitu pemberian ASI kepada bayi yang dilahirkannya. Namun, masih banyak ibu yang mengalami kesulitan dalam menyusui bayinya karena kurangnya produksi ASI. Perawatan payudara dan pijat oksitosin diketahui dapat membantu ibu nifas mengatasi permasalahan produksi ASI. Penelitian ini bertujuan untuk mengetahui perbedaan efek perawatan payudara dan pijat oksitosin terhadap produksi ASI pada ibu nifas.

Penelitian ini dilakukan dengan metode quasi eksperiment dengan memberikan intervensi perawatan payudara dan pijat oksitosin kepada $30 \mathrm{ibu}$ nifas. hasil uji statistik Wilcoxon untuk data perawatan payudara menunjukkan nilai p 0.001 dan uji statistik paired t-test untuk data pijat oksitosin dengan nilai p 0.000. kedua hasil uji statistik menunjukkan adanya kesamaan peningkatan produksi ASI setelah tindakan perawatan payudara dan pijat oksitosin pada ibu nifas.
\end{abstract}

Kata kunci: Perawatan Payudara, Pijat Oksitosin, Produksi ASI

\section{Pendahuluan}

Masa nifas merupakan periode penting dalam hidup seorang ibu dimana pada masa nifas seorang ibu mengalami berbagai macam perasaan, antara lain bahagia karena berhasil mempunyai anak, namun ada kalanya muncul perasaan bingung dengan tanggung jawabnya yang baru sehingga seorang ibu sering mengalami kelelahan yang dapat mengakibatkan penurunan produksi Air Susu Ibu (ASI). ${ }^{1}$ Penurunan produksi dan pengeluaran ASI pada hari-hari pertama setelah melahirkan dapat disebabkan oleh kurangnya rangsangan hormon prolaktin dan oksitosin yang sangat berperan dalam kelancaran produksi dan pengeluaran ASI. Ibu nifas yang tidak mengetahui cara mengatasi penurunan produksi ASI, maka pemakaian susu formula meningkat sebagai pengganti ASI. $^{2}$

Ada beberapa faktor yang dapat mempengaruhi kelancaran produksi dan pengeluaran ASI yaitu perawatan payudara frekuensi penyusuan, paritas, stres, penyakit atau kesehatan ibu, konsumsi rokok atau alkohol, pil kontrasepsi, dan asupan nutrisi. Perawatan payudara sebaiknya dilakukan segera setelah persalinan (1-2 hari), harus dilakukan ibu secara rutin. Pemberian rangsangan pada otot-otot payudara akan membantu merangsang hormon prolaktin untuk membantu produksi air susu ${ }^{2}$. Manfaat tindakan perawatan payudara yaitu melancarkan reflek pengeluaran ASI, meningkatkan volume ASI, dan mencegah bendungan pada payudara $^{3}$

Pijat oksitosin juga dapat membantu mengatasi ketidaklancaran produksi ASI. Pijat oksitosin dilakukan pada sepanjang tulang belakang (vertebrae) sampai tulang costae kelima-keenam. Efek dari pijat oksitosin itu sendiri bisa dilihat reaksinya setelah 6-12 jam pemijatan ${ }^{4}$. Tindakan pijat oksitosin ini dapat memberikan sensasi rileks pada ibu dan melancarkan aliran saraf serta saluran ASI kedua payudara lancar ${ }^{5}$. Selain itu, pijat oksitosin juga berguna dalam membantu rahim berkontraksi untuk mengurangi perdarahan ibu; merangsang produksi hormon lain yang dapat membuat ibu lebih rileks, 
meningkatkan ambang nyeri, dan perasaan bahagia ${ }^{6}$.

Berdasarkan latar belakang diatas, penelitian ini bertujuan untuk mengetahui perbedaan efek perawatan payudara dan pijat oksitosin terhadap produksi ASI pada ibu nifas.

\section{Metode Penelitian}

Jenis penelitian ini menggunakan rancangan penelitian intervensional dan desain penelitian paralel / longitudinal. Metode penelitian yang digunakan adalah quasi eksperimental, dimana data dikumpulkan beberapa hari setelah intervensi (pijat oksitosin atau perawatan payudara) yang dilakukan pada ibu nifas menggunakan lembar observasi (kuesioner terancang). Variable dependen yang diteliti adalah produksi ASI pada ibu nifas, sedangkan variabel independennya adalah pijat oksitosin dan perawatan payudara.

Sampel penelitian yang digunakan adalah ibu nifas dipilih secara acak (random sampling)sebanyak 30 orang yang akan menerima intervensi berupa pijat oksitosin dan perawatan payudara untuk meningkatkan produksi ASI. Responden penelitian akan mengisi kuesioner yang terdiri dari 11 pertanyaan tentang kecukupan ASI sebelum dan sesudah dilakukan tindakan perawatan payudara atau pijat oksitosin.

Data yang terkumpul akan dianalisis menggunakan uji statistik wilcoxon karena setelah dilakukan uji normalitas data didapatkan data yang berdistribusi tidak normal. Sedangkan data kecukupan nilai produksi ASI pijat oksitosin berdistribusi normal, sehingga menggunakan uji statistik paired $T$ test untuk mengetahui peningkatan pijat oksitosin. Hasil dari kedua uji statistik tersebut dinilai keefektifannya dalam meningkatkan produksi ASI.

\section{Hasil dan Pembahasan}

$\begin{array}{ccr}\text { Responden } & \text { penelitian } & \text { yang } \\ \text { digunakan } & \text { berjumlah } & 30\end{array}$
orang.Responden yang mendapatkan tindakan perawatan payudara dan pijat oksitosin masing-masing berjumlah 15 orang. Responden penalitian tersebar dari umur 18-41 tahun dengan berbagai macam latar belakang pendidikan (SD, SMP, SMA, dan S1) dan pekerjaan (IRT, buruh, penjaga toko, dan guru). Ibu nifas yang menjadi responden penelitian juga memiliki variasi paritas primipara sebanyak 16 orang, dan multipara sebanyak 14 orang.

Hasil uji statistik Wilcoxon pada data perawatan payudara yaitu 0.001 yang menunjukkan adanya peningkatan produksi ASI sebelum dan sesudah dilakukan perawatan payudara. Sedangkan hasil uji paired T-test pada data pijat oksitosin adalah 0.000 yang juga menunjukkan adanya peningkatan produksi ASI setelah dilakukan tindakan pijat oksitosin.

Berdasarkan karakteristik responden berdasarkan umur kebanyakan responden berumur 20-35 tahun sebanyak 21 responden (70\%). Umur merupakan salah satu faktor yang dapat mempengaruhi produksi ASI, ibu yang usianya lebih muda akan lebih banyak memproduksi ASI dibandingkan dengan ibu yang usianya lebih tua 7,8 . Sedangkan tingkat pendidikan seseorang tidak dapat dijadikan pedoman bahwa seseorang akan berhasil pada saat proses menyusui. Akan tetapi proses informasi yang benar dan diterima tentang proses menyusui sebelumnya menentukan keberhasilan proses menyusui.

Hasil uji statistik menggunakan uji wilcoxon maupun paired T-test menunjukkan adanya peningkatan produksi ASI sebelum dan sesudah diberikan tindakan berupa perawatan payudara dan pijat oksitosin. Perawatan payudara merupakan suatu kebutuhan ibu yang baru saja melahirkan dan suatu tindakan yang sangat penting untuk memperlancar pengeluaran ASI dengan merangsang payudara yang akan 
mempengaruhi hipofise mengeluarkan hormon progesteron dan estrogen lebih banyak dari biasanya, serta merangsang kelenjar susu melalui pemijatan ${ }^{9,10}$.

Pijat oksitosin merupakan salah satu solusi untuk mengatasi ketidaklancaran produksi ASI. Pijat oksitosin adalah pemijatan pada sepanjang tulang belakang (vertebrae) sampai tulang costae kelima-keenam dan merupakan usaha untuk merangsang hormone prolactin dan oksitosin setelah melahirkan.Pijatan ini berfungsi untuk meningkatkan hormone aksitosin yang menenangkan ibu, sehingga ASI pun otomatis keluar [11]. Pijatan atau rangsangan pada tulang belakang, neurotransmitter akan merangsang medulla oblongata langsung mengirim pesan ke hypothalamus di hypofise posterior untuk mengeluarkan oksitosin sehingga menyebabkan buah dada mengeluarkan ASI nya ${ }^{12}$

Pemberian tindakan tambahan seperti perawatan payudara dan pijat oksitosin dibutuhkan untuk meningkatkan produksi ASI. Kedua tindakan tersebut juga membantu ibu turut serta dalam program ASI eksklusif pada bayi usia 06 bulan.

\section{Kesimpulan}

Berdasarkan hasil uji statistik pada responden penelitian yang menunjukkan kesamaan peningkatan produksi ASI pada ibu nifas setelah diberikan tindakan berupa perawatan payudara dan pijat oksitosin. Petugas kesehatan, khususnya bidan dapat mempromosikan dan melatih ibu dan keluarga untuk melakukan perawatan payudara dan/atau pijat oksitosin sehingga dapat turut serta dalam mensukseskan program ASI eksklusif.

\section{Daftar Pustaka}

[1] Purwanti E, Asuhan Kebidanan Untuk Ibu Nifas. Yogyakarta : Cakrawala Ilmu, 2012

[2] Anggraini Y. 2010. Asuhan Kebidanan Masa Nifas. Yogyakarta: Pustaka Rihanna
[3] Suherni, Widyasih, Rahmawati. 2009. Perawatan nifas normal. Yogyakarta: Fitramaya

[4] Lund I, Moberg U, Wang J, Yu C, Kurosawa M, Massage affect nociception of oxytocin, J.European neuroscience Vol 16:330-338, 2002

[5] Amin M, Jaya H, Efektivitas Massase Rolling (Punggung) terhadap Produksi ASI pada Ibu Post Operasi Sectio Secsarea di Rumah Sakit Muhammadiyah Palembang, Poltekkes Palembang, 2011

[6] Roesli U. (2012). Inisiasi Menyusu Dini Plus Asi Eksklusif.Jakarta: Pustaka Bunda

[7] Biancuzzo M, Breastfeeding the newborn: Clinical Strategies for Nurses, St Louis: Mosby, 2003

[8] Suraatmadja, Aspek Gizi Air Susu Ibu. Dalam: ASI Petunjuk Untuk Tenaga Kesehatan, Editor: Soetjiningsih, Jakarta:EGC, 2001

[9] Nilamsari MA, Wagiyo, Elisa, Pengaruh Perawatan Payudara terhadap Kelancaran Ekskresi ASI pada Ibu Post Partum di Rumah Sakit Mardi Rahayu Semarang. Jurnal Ilmu Keperawatan dan Kebidanan, 2014

[10] Ambarwati dan Wulandari, Asuhan Kebidanan Nifas. Yogyakarta: Mitra Cendekia Press, 2008

[11]Purnama RRW, Skripsi, Efektifitas Antara Pijat Oksitosin dan Breast Care Terhadap Produksi ASI Pada Ibu Post Partum Dengan Sectio Caesarea di RSUD Banyumas, Unsoed, 2013

[12]Mardiyaningsih E, Tesis, Efektifitas kombinasi teknik marmet dan pijat oksitosin terhadap produksi asi ibu post seksio sesarea di Rumah Sakit Wilayah Jawa Tengah, UI: Fakultas Ilmu Keperawatan, 2010 
